\title{
The Influence Of The Basic Knowledge Of Noble Truth and The Implementation Of Mindfulness On Spiritual Development Of Buddhist People at Mahabodhi Temple-Semarang
}

\author{
Partono $^{1}$, DYP Sugiharto ${ }^{2}$, Tri Joko Raharjo ${ }^{3}$, Titi Prihatin ${ }^{4}$ \\ \{psnadi@smaratungga.ac.id ${ }^{1}$, dypsugiharto@mail.unnes.ac.id ${ }^{2}$, trijokoraharjo@mail.unnes.ac.id ${ }^{3}$, \\ titiprihatin@mail.unnes.ac.id $\left.{ }^{4}\right\}$
}

\author{
Sekolah Tinggi Ilmu Agama Buddha Smaratungga Boyolali, Indonesia ${ }^{1}$ \\ Graduate School Unniversitas Negeri Semarang J1. Kelut Utara Semarang, Indonesia²,3,4
}

\begin{abstract}
Human beings are considered having basic potentialities to be happy and suffer. Spiritual development is an ability to think critically, have self-understanding, liable consciousness and development of mindfulness. This research aims at finding out the influence of the basic knowledge of noble truth and the implementation of mindfulness on the spiritual development of Buddhist people at Mahabodhi Temple. The research result found that the basic knowledge of four noble truths does not have a significant influence on spiritual development; the correlation coefficient was 0.906 showed a fragile correlation level. The result of the correlation coefficient test (0.029) of the influence of the implementation of mindfulness on spiritual development showed a significant value. The correlation coefficient number of the application of mindfulness which was 0.488 showed a unidirectional relationship between the practice of mindfulness and spiritual development, which was like the practice of mindfulness develops, the spiritual development would also develop, too.
\end{abstract}

Keywords: dukkha (suffering), mindfulness, spiritual development.

\section{Introduction}

The journey of Buddhist people in Southeast Asia, especially in Indonesia, believed in religious through a ritual approach rather than learning the teaching of Buddhism as spirituality. Generally, they acknowledged the existence of a spiritual dimension in humans besides the physical aspect, the meaning of life and the desire for living the will of meaning is the primary motivation for humans to achieve the meaning of life [1] which was coveted. The wish to live a meaningful life could be lead in various conditions, whether in a reasonable condition or when facing suffering (dukkha) [2]; [3] for instances: when in pain, guilt, even on the deathbed as well.

Spiritual development is a mental capacity which gives a contribution to one's consciousness, integrity, and adaptive application non-material aspect and transcendent existence, leads to results such as deep existential reflection, increase in meaning, selfrecognition transcendent, and mastering the spirituality. There are four main components of 
spiritual development, as (1) critical thinking, (2) personal meaningfulness, (3) transcendental awareness, and (4) development of consciousness [4].

The spiritual development in this research was referring to (1) the ability to being flexible, adaptive; (2) having self-awareness; (3) being able to face and resolve suffering and painful feeling; having knowledge, vision, broad and ethical values; (5) always seeing everything wholly and interconnected; (6) being able to face and using everything with positivity; (7) independent; (8) capable of and his/her existence is recognized.

Human existence and meaning of life are (1) every condition, including suffering, this life always has a meaning; (2) desire for living the will of meaning is the primary motivation; (3) a human being has freedom and personal responsible to choose, determine and fulfill his/her life's meaning and goal; (4) meaningful life is achieved by realizing three values of life, such as: creative values, experimental values and attitudinal values.

The first noble truth of suffering (dukkha) is the first insight [5]; [6]. The knowledge which is intended is not to make the suffering to be something excellence, but merely to understand it as suffering, and this is essential insight. The second noble truth has three main aspects, as there is a source of suffering which is craving, let the origin of suffering pass away, and has let the source of suffering passed away (S.V.420). The realisation of the third noble truth can be done by seeing the suffering and nature of its causes naturally. Seeing everything as they are will give rise to wisdom to let all sensations of suffering pass away without causing suffering [6].

The fourth noble truth has three main aspects, as there is a way to get rid of suffering, the way to be cultivated, and the way has been cultivated. The way to get rid of suffering is the eightfold path which consists of the groud of wisdom, namely: right understanding and right intention or aspiration. The group of wisdom will lead to moral commitment, including right speech, right action, and right livelihood. Naturally, morality will lead to the right effort, right mindfulness and right concentration.

Process of mindfulness is an internalisation process to see the present which happens each moment in this life (sammā samādhi). Some particular research confirms one of the benefits of Buddhist meditation (mindfulness) [10] is: having a chance to use severe conditions and disturbing emotions that usually appear together open the key to the strength and potency of the human mind. The process of internalisation affects meaningful life or human spirituality.

\section{Methods}

The research approach is quantitative. Research experimental design is carried out with carefully regulated procedures in which one or more factors considered to influence the behaviour being studied will be manipulated, and all other factors are considered constant. The experience design is one group of posttest design. Before the treatment, the sample was not given a pre-test (initial test), but only at the end of the training, post-test was conducted (final test).

Participants consist of 8 males and 12 females $(\mathrm{N}=20)$ who joined the training of noble truth and mindfulness practice. The procedure of the training of noble truth was conducted for 60 minutes, and mindfulness practice was conducted for 30 minutes every week during one semester. Research data collection used questionnaire which was arranged by the researcher using the Likert scale model. Spiritual development questionnaire consists of 12 items, basic knowledge of noble truth 19 items, and mindfulness practice 24 items, in total 55 items. 


\section{Results and Discussion}

Descriptive statistics and the response distribution of the results of the research instrument trialled for the Spiritual Development variable were all significant. While doing the instruments trial of the basic knowledge of noble truth, it was found that there were five items which were not significant. There were four items of the instrumental variable of the mindfulness practice result which were not significant. All non-significant items were not used. The spiritual development of Cronbach's alpha is 0.914 , the basic knowledge of noble truth was 0.890 , and the mindfulness practice is 0.934 suggesting very high internal consistency and reliability [11]; [12].

The result of the descriptive analysis variable of the spiritual development of Buddhist people at Mahabodhi Temple resulted in the recapitulation of critical thinking calculations with an average of 3.55 or $71 \%$ at the high category level. Indicators recapitulation of personal meaningfulness showed an average of 3.70 or $75.7 \%$ in the high category level. The average indicator of transcendental awareness was 3.65 or $73 \%$ in the high category level. And, the decryption of development indicators ranged from an average of 3.40 or $68 \%$ in the high category level.

The result of the analysis research description of the basic knowledge of noble truth variable of the Buddhist people at Mahabodhi Temple resulted in a critical recapitulation of an average of 3.55 or $71 \%$ in the achievement of the high category. It was considered that Buddhist often contemplated what was happening after death. After developing their theories, such as life, death, reality and existence. And also, contemplating on the meaning of experiences happened in their life. Personal meaningfulness showed high category level.

Transcendent awareness was related to recognising the nonmaterial or spiritual aspects that existed within oneself rather than physically - being aware of the nonmaterial or spiritual aspects of life that exist within. As well as being aware of nonmaterial or spiritual aspects, it could help oneself to be more focus. Development of consciousness was parallel to being able to explore spiritual awareness, manage spiritual awareness.

The average of the description of research results of the basic knowledge of noble truth variable of the Buddhist people at Mahabodhi Temple from the indicator which showed that there were suffering was 4,1 or $81.2 \%$ in the high-level category level; the cause of suffering averaged of 4.02 or $80.3 \%$ in the high-level category level; the cessation of suffering averaged of 3,63 or $72.7 \%$ in the range of high category; and the way leading to the cessation of suffering averaged of 4.25 or $85 \%$ in very high category.

Understood that birth was suffering, understood that ageing was suffering, understood that being separated with the loved one was suffering. Understood that not being able to get what was wish to was suffering and lamentation was suffering. Realised that craving was the cause of suffering, realised that desire for being born was the cause of suffering. It was realised that the desire for annihilation was the cause of suffering. It knew that the cessation of desire was the cessation of suffering. It knew that the cessation of the desire for being born was the cessation of suffering.

Analysis description of the results of the variable of the implementation of the Mahabodhi Buddhist mindfulness from each indicator of body contemplation on average 4 or $80 \%$ in the high-level category, contemplation on feelings averaged 3.69 or $74 \%$ in the high category, contemplation on awareness averaged 3.61 or $72 \%$ in the high category range, and contemplation on mind on averaged 3.84 or $77 \%$ in high categories.

The mindfulness practice by the Buddhist people from each indicator of the contemplation on the body was in the high category. This was related to realising the breath in 
and out, being aware when walking, being able to observe the outside body, realised that in the body there was a disgusting defilement, realised that the body has solid, liquid, hot, and air elements. Realising the corpse which was buried will go through a process of destruction.

Contemplation on feelings was related to realising the pleasant feelings when it arose, realising the unpleasant feelings when it arose. Realising the pleasant and unpleasant feelings when they arise, realising the pleasant feeling related to material things, and realising the unpleasant feeling related to none-material things.

Contemplation on the awareness of interconnectedness was by realising when experiencing pleasant feelings. Being aware of when experiencing unpleasant feelings being aware when experiencing uncomfortable and unpleasant feelings - being aware when experiencing material pleasures - being aware when experiencing unpleasant feelings which were related to material things. Contemplation on mind-objects gave an insight into oneself that there was a sensual desire within oneself.

Based on the analysis using the Pearson correlation, the significance value of the basic knowledge of noble truth was 0.906 . Because of the number was above $5 \%$, Ho was accepted, meaning that the basic knowledge of noble truth did not have a significant relationship to spiritual development. Also, the correlation coefficient number of the basic knowledge of noble truth of 0.028 showed that there was no inverse relationship between the basic knowledge of noble truth and spiritual development, even though the basic knowledge of noble truth increased, the spiritual development would not increase. Bodhi [13] explained that one of the bases for developing mindfulness was the basic knowledge of noble truths.

The insight of suffering could be achieved by practising mindfulness (satipatthāna) on the body, feelings, thoughts, and various phenomena. New insight or understanding of physical and mental reality could only be achieved by direct observation or attention. Direct attention was something real and was focused on the root of the problem so that it produced a very useful view. Increased attention would lead to a thorough understanding and problem-solving.

The second correlation coefficient test was conducted to explain the influence of the relationship between the implementation of mindfulness and spiritual development. The significance value in the implementation of mindfulness was 0.029 . Because of the number was below $5 \%$, Ho was rejected, which meant that the implementation of mindfulness had a significant relationship to spiritual development. Besides, the number of correlation coefficients for the implementation of mindfulness of 0.488 showed that there was a unidirectional relationship between the implementation of mindfulness and spiritual development, where if the implementation of mindfulness increased, spiritual development would also increase.

Spiritual development (the meaning of life) were (1) considering the existence of spiritual potential and resources were universal for everyone regardless of their race, beliefs and religion; (2) realizing the sources and potential were often suppressed, hampered and even ignored; (3) use these resources to revive from the difficulties and develop themselves to achieve a better quality of life.

The conclusion of the research results description showed that the training in deepening the basic knowledge of noble truth and the practice of mindfulness showed good results at a high level. The implementation of mindfulness had a significant influence on the spiritual development of Buddhist people at Mahabodhi Temple - Semarang. The basic knowledge of noble truth did not affect spiritual development. It was supposed that conceptual understanding did not directly affect spiritual development, requiring further research. 
Acknowledgement. Appreciation to the administrators of the monastery and Maha Bodhi Buddhists who have taken responsibility in training mindfulness and increasing the basic knowledge of noble truth. Seminar committee To the International Conference on Science, Education and Technology, Enhance international collaboration for the acceleration of digital literacy to balance the $\mathrm{i}-4 . \mathrm{O}$ era in humanitarian education. 


\section{Reference}

[1] R. Persaud, Mindfulness and Acceptance: Expanding the Cognitive-Behavioral Tradition. 2006.

[2] N. J. Albrecht, "Teaching mindfulness with children: Being a Mindful Role Model," Aust. J. Teach. Educ., vol. 43, no. 10, pp. 1-23, 2018.

[3] Anālayo, "Right View and the Scheme of the Four Truths in Early Buddhism, The Samyuktaāgama Parallel to the Sammāditthi-sutta and the Simile of the Four Skills of a Physician," Can. J. Buddh. Stud., vol. 7, no. 7, pp. 11-44, 2011.

[4] D. B. King and T. L. DeCicco, "A Viable Model and Self-Report Measure of Spiritual Intelligence,” Int. J. Transpers. Stud., vol. 28, no. 1, pp. 68-85, 2009.

[5] A. Amaro, "A Holistic Mindfulness," Mindfulness (N. Y)., vol. 6, no. 1, pp. 63-73, 2015.

[6] J. Kristeller and L. Rapgay, "Buddhism: A blend of religion, spirituality, and psychology.," APA Handb. Psychol. Relig. Spiritual., vol. 1, no. 1, pp. 635-652, 2013.

[7] S.V., Samyutta Nikāya (The Book Of The Kindred Saying) Vol. V. Translated Davids, Rhys. 1989. Oxford: The Pali Text Society.

[8] D., Dāgha Nikāya (The Long Discourses of the Buddha) Translate by Maurice Walshe. 1995. Boston: Wisdom Publication.

[9] M., Majjhima Nikāya (The Middle Length Discourses Of The Buddha) Translate by Bhikkhu Nanamoli and Bhikkhu Bodhi. 1995. Boston: Wisdom Publications.

[10] M. Hoyt, "Teaching with Mindfulness: Pedagogy of Being-with/for and Without Beingwith/for," J. Curric. Theor., vol. 31, no. 1, pp. 126-142, 2016.

[11] D. M. Mather, Research and Evaluation in Education and Psychology, no. c. USA and Canada: Sages, 2015.

[12] J. Ammitzbøll, A. M. Skovgaard, B. E. Holstein, A. Andersen, S. Kreiner, and T. Nielsen, "Construct validity of a service-setting based measure to identify mental health problems in infancy,” PLoS One, vol. 14, no. 3, pp. 1-18, 2019.

[13] P. Square and M. Park, Mindfulness Diverse Perspective on its Meaning, Origins and Applications. Canada: Routledge, 2013. 